\title{
Manichaean Networks: The Social Networks of the Laity
}

In this chapter, we turn from individual expressions of religious identity to the question of the social groups in which Manichaean affiliation can be traced. The previous chapter has already given some indications as to in what circles we find it, as we considered Manichaean identity within the Pamour family, whose members were traders, camel drivers, and weavers. However, the overlap between the religious network and the family's other networks remains to be explored. Was Manichaean affiliation restricted to certain social contacts or contexts, or did it permeate different networks and types of social relations? At what other 'social sites', to use the vocabulary of David Frankfurter, do we find Manichaeans? And how widespread was it within Kellis? Below, we examine Manichaean affiliation within several different networks tied to the Pamour family: within the family, between neighbours and colleagues, and in patron client relationships. We also go beyond the Pamour family, attempting to see how widespread it was in the village at large. Finally, we consider the nature of the network: how Manichaean affiliation may - or may not - have affected it in relation to adherents' interaction with their social surroundings.

The Social Composition of Manichaeism

Before turning to these questions, we need to look at previous scholarship on the movement's social character. Scholars have often proposed hypotheses, or made assumptions, concerning Manichaeism's size and composition in the course of explaining its success - and failure - in the Roman Empire. In contrast to the early Jesus movement, which is usually presented as originating in the countryside but achieving lasting success in the cities, ${ }^{1}$ Manichaeism was at home in the cities from its inception. Mani preached in several of the urban

1 A recent work discussing (and challenging) this 'urban thesis' of Christianity's success is Thomas A. Robinson, Who Were the First Christians? Dismantling the Urban Thesis (New York: Oxford University Press, 2017).

(C) HÅKON FIANE TEIGEN, 2021 | DOI:10.1163/9789004459779_007

This is an open access chapter distributed under the terms of the CC BY-NC-ND Ato license. Teigen - 9789004459779 
centres of the Sasanian Empire, not least in the capital, Ctesiphon itself. ${ }^{2}$ Among the social groups that his mission is assumed to have appealed to, three have long been considered key to the movement's success - all, at least in the Roman Empire, linked to life in the cities: political elites, merchants, and intellectuals.

Regarding political elites, Manichaean accounts themselves often hail the support of influential backers at important moments in the history of the Church, depicting Mani and his disciples converting nobles and potentates in the Sasanian realm. In turn, this has been taken to indicate a conscious missionary strategy by modern scholars. ${ }^{3}$ Zooming in on the Roman orbit, the only patron the Manichaeans are known to have claimed for their Church was queen Zenobia of Palmyra. ${ }^{4}$ Tardieu argued that the support of Zenobia might account for the arrival of the mission of Adda in Egypt, which he dated to $c .270$, when the short-lived Palmyrene Empire brought this area under its control. ${ }^{5}$ However, the argument has not won general acceptance. ${ }^{6}$ Otherwise, no supporter of major political influence is known with certainty from the Roman Empire. ${ }^{7}$

The importance of merchants, on the other hand, is well established. It has even been claimed, with some exaggeration, that 'merchant and Manichaean must for some time have been practically synonymous. ${ }^{8}$ Merchants, too, figure in literary depictions, both Manichaean and anti-Manichaean ones, ${ }^{9}$ and

2 Although it should be pointed out that one of the first locations where we meet him after his break with the baptists, according to the CMC (111), is Naser, a village on the outskirts of the capital.

3 Lieu, Manichaeism in the Roman Empire, 58-59; Paul C. Dilley, 'Religious Intercrossing in Late Antique Eurasia: Loss, Corruption, and Canon Formation', Journal of World History 24, no. 1 (2013): 62ff.

4 In particular, see the leaf of the Acts Codex (P 15997) provisionally published in Nils A. Pedersen, 'A Manichaean Historical Text', Zeitschrift für Papyrologie und Epigraphik 119 (1997).

5 Tardieu, 'Les manichéens en Égypte', 10.

6 A more indirect role of the Palmyrenes is suggested by Lieu, Manichaeism in Mesopotamia, 35 .

7 A possible exception is Sebastianus, dux of Egypt (356-358) and a general who fought with Valens at Adrianopolis, whom Athanasius accused of being a Manichaean. The truth value of this accusation is doubted by many scholars, and strongly rejected by Tardieu, 'Sebastianus étiquté comme manichéen', Klio 70, no. 2 (1988).

8 Maenchen-Helfen (1951), cited in Peter Brown, 'The Diffusion of Manichaeism in the Roman Empire', The Journal of Roman Studies 59, no. 1/2 (1969): 102.

9 For Manichaean texts, see CMC 144-45, and P 15997 (pl.99, l.14) in Pedersen, 'A Manichaean Historical Text'. For anti-Manichaean texts, see e.g. the portrayal by Epiphanius of Mani as recipient of all his ideas from the 'Saracen' merchant Scythianus (Panarion 3.66.1.8-4.1); Frank Williams, The Panarion of Epiphanius of Salamis, Books II and III, nnd ed. (Leiden: Brill, 2013), 227-31). 
mercantile metaphors were a staple of Manichaean poetical imagery. ${ }^{10}$ Sogdian traders were central for the spread of the religion in Central Asia, and Syrian merchants have been suggested as facilitating its spread to Egypt. ${ }^{11}$ Peter Brown took the fifth-century decline in Rome's eastern trade as one important factor in the simultaneous decline of Manichaeism. ${ }^{12}$ Anecdotal evidence is supplied by Augustine's biographer, Possidius, who relates that Augustine once converted a Manichaean merchant, Firmus, through a providentially side-tracked sermon..$^{13}$ However, Manichaeism is certainly not the only religious group whose dissemination can be connected to trade routes and merchant activity, and so one may question the extent to which Manichaeism presented a special case in this regard. ${ }^{14}$

Finally, the somewhat nebulous group of 'urban intellectuals' has been seen as an important source of Roman adherents. The chief example is the circle of Augustine, but the philosopher Alexander of Lycopolis, who wrote not long after the movement had arrived in Roman Egypt, relates that fellow-philosophers had taken an interest in the teachings. Émile G. de Stoop even described Manichaeism as primarily influential among intellectuals, while Lim argued that 'Manichaeans' so-called may be better seen as philosophically inclined Christians, sharing an interest in Mani's books and ideas. ${ }^{15}$

Alongside appealing to these mostly urban-based elites, it has been widely assumed that Manichaeism mainly made inroads in previously Christianised environments, among adherents of (some form of) Christianity. Already Ephrem the Syrian claimed that Mani took his adherents from Marcion, who in turn had seduced people from the 'Catholic' Church. ${ }^{16}$ Adolf von Harnack, writing of gnostic movements in general, asserted that ' $\mathrm{t}]$ he principles and doctrines of these Gnostic communities were such that it was not easy for them to gain any adherents except where some Christianity had gone before them. This is true of the Manichaean movement in the fourth century. ${ }^{17}$ Similarly, Brown

10 See Widengren, Mesopotamian Elements, 82-95.

11 Lieu, Manichaeism in the Roman Empire, 69-78; Guy G. Stroumsa, 'Monachisme et marranisme chez les Manichéens d'Egypte', Numen 29, no. 2 (1982), 186.

12 Brown, 'Diffusion of Manichaeism', 102.

13 Vita Augustini 15, cited and translated in Gardner and Lieu, Manichaean Texts, 142-43.

14 See for instance Christianity's spread through merchant networks on the Red Sea. Eivind H. Seland, 'Early Christianity in East Africa and Red Sea/Indian Ocean Commerce', African Archaeological Review 31, no. 4 (2014).

15 Émile G. de Stoop, Essai sur la diffusion du manichéisme dans l'empire romain (Ghent: Université de Gand, 1909), 6-7, 42-51; Lim, 'nomen manichaeorum', 160.

16 Lieu, Manichaeism in the Roman Empire, 44.

17 Adolf von Harnack, The Expansion of Christianity in the First Three Centuries. Vol. 2, trans. James Moffatt, 2nd ed. (London: G. P. Putnam's Sons, 19o8), 307-8. 
claimed that 'traditional pagans seem always to have regarded the Manichees with horror; but the Christians were less certain. ${ }^{18} \mathrm{He}$ took the majority of the movement's Auditors to have come from the 'fringe' of Christian communities (at least by the later period). Still, this view has seen criticism, and does not capture all the available evidence. ${ }^{19}$ Furthermore, while Manichaeans have been seen as mainly appealing to Christians, it has conversely been assumed that they did not gain much ground in areas that were 'orthodox'. Harnack, as we saw above, emphasised recruitment from (other) Gnostic groups. De Stoop opined that while Christians influenced by Greek or 'Oriental' ideas, and some pagans, found Manichaeism attractive, Catholics were impervious. ${ }^{20}$ In part, the difficulties of Manichaean missionaries have been associated with the growth of Christian ecclesiastical power. ${ }^{21}$ At times, however, it has also been linked to the notion that Manichaean teachings were too complex - or 'strange' - to make headways among non-elite groups, or groups not already familiar with Christian thought. William H. C. Frend noted how Manichaean asceticism and fervour attracted members from different classes, but that its overly complicated doctrines held it back from becoming a mass movement, 'especially when compared to the simplicity of orthodox Christianity'. ${ }^{22}$ Similarly, parts of its doctrinal tenets could be seen as a limiting factor. Farmers made up the vast majority of the inhabitants of the Roman Empire, and would (one might assume) have little interest in Manichaeism, considering its hostile view of their occupation - as opposed to for instance merchants, who could be drawn to the status the movement allotted them.

This elitist mission, combined with difficult doctrines, have been taken to signify that the Manichaeans were unable to appeal to the general populace whose support would have been necessary to build a broad movement. It is further argued that, as a consequence of their small following, local Manichaean

18 Brown, 'Diffusion of Manichaeism', 98.

19 Jason D. BeDuhn (Augustine's Manichaean Dilemma I, 107) has noted that several of Augustine's Manichaean associates - Honoratius, Nebridius, and Faustus himself - had all been 'pagan' before they converted to Manichaeism. Pedersen (Demonstrative Proof, ${ }^{158-71)}$ has pointed out that Titus of Bostra's treatise against the Manichaeans was addressed to both a Christian and a 'pagan' audience.

20 De Stoop, Essai sur la diffusion, 32. The view of Manichaeism as a 'parasite' on Christian or gnostic hosts has been criticised in Williams, Rethinking "Gnosticism", 93-94.

21 So for instance Brown, 'Diffusion of Manichaeism', 101.

22 W. H. C. Frend, The Rise of Christianity (Philadelphia: Fortress Press, 1984), 456 (and see 568-69). Robin Lane Fox, on the other hand, questioned how Mani's 'bizarre "myth" could ever appeal to people in very high society', Pagans and Christians in the Mediterranean World from the Second Century AD to the Conversion of Constantine (London: Viking, 1986), 57 o. 
communities were largely organised into small, tight-knit units, or 'cells' (translating the Latin conventicula), of lay believers who serviced the itinerant Elect. ${ }^{23}$ We return to the question of the movement's organisation in Kellis in Chapters 8 and 9; in the following, we focus on size and social composition, although it should be noted that the two questions are related. If the community in Kellis was restricted to a particular household or occupational group for instance the extended Pamour family, - such a cell organisation would be the only option available to them. But as we shall see, the Kellis evidence challenges the depiction of Manichaeism as a movement of limited appeal. Here, at least, the group had a more diversified and widespread dissemination than is often allowed for.

Manichaean Social Networks

Considering the emphasis on urban elites and environments, it comes as something of a surprise to find Manichaeans settling in a provincial village at Empire's edge. Their presence in this remote location has at times been explained by persecution. Samuel N. C. Lieu suggested that the first Manichaeans at Kellis were missionaries who had fled Diocletian's persecution in 302, arguing that ' $[\mathrm{t}$ ] he Dakhleh oasis offered more shelter for the sect, probably because it was less overseen by imperial administrators and also less Christianised. ${ }^{24}$ He noted that House 3 could have functioned as a safe house and centre for proselytising for the beleaguered group. This might receive support from the Syriac texts and translation tools found at the site, which could imply that Syrian missionaries were present here. However, as Franzmann has shown, the bilingual texts found at Kellis were not the products of native Syriac speakers but rather tools for Egyptians learning to write Syriac. ${ }^{25}$ To this it might be added that the use of Syriac was not restricted to the community's earliest phase: a letter from the mid-fourth century mentions a 'brother' Ision who had been taught to read Syriac (P.Kellis I Gr. 67). Furthermore, as we saw in Chapter 2, a Roman military unit had its home in the Oasis, based just

23 See e.g. de Stoop, Essai sur la diffusion, 34ff; Brown, 'Diffusion of Manichaeism', 97; Frend, The Rise of Christianity, 661; Lieu, 'Precept and Practices', 78-79; BeDuhn, 'Domestic Setting', 26o. For a criticism of the term 'cell' (but not the underlying 'cell behaviour'), see Lim, 'Unity and Diversity', 231.

24 Lieu, Manichaeism in Mesopotamia, 98.

25 Majella Franzmann, "The Syriac-Coptic Bilinguals from Ismant el-Kharab (Roman Kellis): Translation Process and Manichaean Missionary Practice', in Il Manicheismo. Nuove prospettive della ricera, ed. A. van Tongerloo and L. Cirillo (Turnhout: Brepols, 2005), 120-22. 
outside of Trimithis; there was no lack of Roman power there. Other explanations for its dissemination in Kellis and in the Oasis must be sought.

The Pamour family must necessarily be our starting point for exploring both the spread and social character of the Kellis community. Below, we examine the role of Manichaean affiliation in four different social sites - family, neighbourhood, trade, and patronage, each with an associated network. When considering the religious affiliation of actors in these networks, we should be careful not to take a 'guilt by association' approach. Presence in the family's network alone is not enough to establish an actor as co-adherent, and so each context has to be examined carefully.

\subsection{Familial Networks}

If Manichaeans arrived as refugees they certainly did not remain so: by the mid-fourth century they were firmly entrenched in local society. The households of local families would have been particularly important sites of religious activity. In a recent study drawing on the Kellis papyri, BeDuhn has situated the day-to-day forms of Manichaean ritual in the domestic, familial setting. ${ }^{26}$ Individual lay practices, such as daily prayers and religious study, would have been centred in the domestic sphere. BeDuhn also argues that the Kellis evidence attests to a domestic context also for activities such as psalm singing and readings of scripture, and the receiving of itinerant Elect into lay homes. Yet the domestic character of Manichaeism should not be exaggerated. BeDuhn himself notes that the situation in Kellis may have been more complex. ${ }^{27}$ As we shall see in Chapters 8-9, there is strong evidence for more institutionalised forms of worship in the village, including the existence of a communal gathering place.

Rodney Stark has suggested that religious affiliation primarily moves through pre-existing social networks; a 'structure of direct and intimate interpersonal attachments'. ${ }^{28}$ In light of this proposition, it is likely that familial ties also provided a primary locus for the spread of adherence, especially considering the density of the Pamour family network we saw in Chapter 4. The evidence from the letter contents confirms this supposition. As we saw in the last chapter, distinctly Manichaean cues can be found in all the House 3 circles, barring only the Petros letters, in letters by key members such as the siblings Pekysis, Pamour III, and Tekysis III, and Pamour's father-in-law, Makarios. Most of the other family members were certainly also adherents. Psais III, Maria I and II, Partheni II, Psenpnouthes I, Kyria I, Philammon II, Horos I, Tehat,

\footnotetext{
26 BeDuhn, 'Domestic Setting'.

27 Ibid., 261.

28 Stark, The Rise of Christianity, 20. See also Harland, Associations, 38-44.
} 
Theognostos, and Andreas are all greeted with distinctly Manichaean cues, and those of whom we have preserved letters invoke shared religious affiliation, even if mostly using less explicit cues.

Naturally, adherence could vary between family members and between family groups. The strongest expressions of Manichaean identity are found in the circle of Pamour III's in-laws, Maria/Makarios. ${ }^{29}$ The difference between this circle and the Pamour/Pekysis circle has recently been attributed to a lessening of faith in the later generation, ${ }^{30}$ but this hypothesis is not, to my mind, tenable. The brothers Matthaios and Piene, who used elaborate cues and were closely affiliated with the Elect, were of the same generation as Pamour III and Pekysis. Moreover, the latter's younger brother, Psais III, is found copying religious texts on behalf of the community in a letter dated c.370 (see Chapter 7, Section 3.2). We might, moreover, contrast the only preserved letter of 'father' Psais II, P.Kellis vII Copt. 110, which does not utilise Manichaean or other religious cues at all - on the basis of which one might argue that Manichaean faith became more important in the succeeding generation of his sons. Linguistic variation between familial circles, whether due to differences in educational level, priorities, or opportunities to engage, provides a more likely explanation than generational differences.

The importance of family bonds isnotleastseen in the crucial role that women played in Kellis. While most - but not all - of the authors using religious cues were men, as were the majority of authors more generally, a large percentage of the recipients (especially of Coptic letters) are women. ${ }^{31}$ The importance of women in economic terms has already been explored for figures such as Tehat, Partheni II, and Tekysis III. These and other women are also found to have played

29 As it is possible that Pamour's wife originated in the Nile Valley (P.Kellis I Gr. 30, see Chapter 3, Section 1.1), one might speculate that their marriage was meant to strengthen bonds between Manichaeans in the Oasis and the Valley.

$30 \quad$ The editors of P.Kellis VII noted: 'Manichaean faith is vitally alive and a central concern for Makarios and his sons; in contrast, whilst there is still evidence for it in the Pamour documents, it is rarely so overt. Whether this is a result of increased circumspection, or a diminishing of faith, we simply cannot say' P.Kellis VII, 41. More strongly, Mattias Brand has argued: 'When we compare the letters of Makarios and Pamour III, despite all shortcomings of such a comparison, it seems that the younger generation used less elements from a Manichaean repertoire, indicating that they might have been less deeply involved in the community.' Brand, 'Manichaeans of Kellis', 164.

31 The editors reckon that the total Coptic letters where a woman is either author (including co-authorship) or primary recipient constitute, roughly, more than $40 \%$ (the majority being recipients). See P.Kellis VII, 13-14. 
a vital part in the religious life of the community. ${ }^{32}$ Tehat was closely involved in organising almsgiving to the Elect, as we will explore in Chapter 8. Maria I was responsible for practical arrangements surrounding the religious education of Matthaios before he went to the Valley, as well as for supporting Makarios and Piene there. While Maria I's support was mediated by Makarios, other women, such as Eirene, were addressed directly by the Elect for contributions (P.Kellis v Copt. 32). One Elect author even addressed the women of Kellis as a collective, praising their great piety while at the same time requesting alms (P.Kellis v Copt. 31). Women were not restricted to practical arrangements: they also had leading roles in religious contexts. In P.Kellis v Copt. 25, Matthaios laments the death of his 'great mother' in the Valley who had died without receiving a proper gathering by the 'brotherhood'; she had clearly been a woman of high regard. Mother Kyria I kept a large copy of the Epistles (likely those of Mani, see Chapter 7), which Makarios requests Maria I to retrieve and send in P.Kellis V Copt. 19. It is unlikely that Kyria would have kept the book and, as Makarios implies, been unwilling to part with it, if she did not have use for it, and so she may well have been literate. Religious affiliation was clearly deeply embedded in the whole extended family.

\subsection{Neighbourhood Networks}

In Chapter 4, we were introduced to the neighbours visible in texts found in House 2 of the House 1-3 complex: the carpenters Tithoes I son of Petesis and Ploutogenes son of Pataias. The finds of a Manichaean literary text in House 2, P.Kellis I Copt. 8, should itself alert us to the likelihood that the circles of Tithoes I and Ploutogenes shared in the religious community of the Pamour family. To this it should be added that many of the Manichaean literary texts found in House 3 were written on wooden boards, a fact that may well have had something to do with these two men's background as carpenters. ${ }^{33}$ Furthermore, for Tithoes I, evidence from the letters can be adduced in support. Tithoes I relayed greetings to his son Samoun from 'brother' Psenpnouthes and 'sister' Kyria in P.Kellis v Copt. 12; a couple who were clearly Manichaean Auditors. Although not certain, a religious context could well have framed Tithoes I's use

32 For more extensive treatments of the role of women at Kellis and in Manichaeism in general, see the studies of Majella Franzmann, 'Tehat the Weaver: Women's Experience of Manichaeism in Fourth-Century Roman Kellis', Australian Religion Studies Review 20, no. 1 (2007); ead., 'Manichaean Almsgiving'; Scopello, Femme, gnose et manichéisme; J. Kevin Coyle, 'Prolegomena to a Study of Women in Manichaeism', in Manichaeism and its legacy (Leiden: Brill, 2009); Johannes van Oort, 'Manichaean Women in Augustine's Life and Works', in Vigiliae Christianae 69 no. 3 (2015).

For Manichaean texts on wooden boards, see T.Kellis II Copt. 1-7. 
of kinship terms here. More revealing is the relationship between his 'daughter' Tapsais II and the Pamour family. P.Kellis viI Copt. 116, a letter she authored to Psais III - where she also greets her father Tithoes I - invokes shared religious belief, using what might, albeit uncertainly, even be a distinctly Manichaean expression. ${ }^{34}$ Tapsais II is greeted in letters with distinct Manichaean cues; for instance in P.Kellis VII Copt. 65, where Pamour III employed the tripartite prayer. Similarly, in P.Kellis vir Copt. 86, whose distinctively Manichaean opening is partly preserved, ${ }^{35}$ the legible part of the greeting section reads: 'greet the neighbourhood (Трдоүн) for me [...] Tapshai' (ll.8-9).

Considering this evidence, the Tithoes family can, with a fair amount of certainty, be taken to have shared the religious affiliation of their next-door neighbours. Their level of commitment may, moreover, have been high. In P.Kellis I Gr. 12, Samoun requests his father to send his son, Tithoes II, to a monastery in order to learn linen weaving - and in his response in P.Kellis V Copt. 12, his father affirmed that the boy has indeed been sent with 'father' Pebok. It is likely that Tithoes II's apprenticeship at the monastery should be seen within a Manichaean framework, a point to which we return in Chapter 9.

\subsection{Occupational Networks}

Given the strong links often assumed between Manichaeism and merchants, the Pamour family's involvement in textile trade is perhaps not particularly surprising, but how trading and religious affiliation intertwined needs further explication. Communication networks certainly played a part. In the early fourth century, Pamour I sent tunics to Hermopolis, while his neighbour Horos son of Mersis drove his camels to the same city. A few decades later, Pamour III, Pekysis, and Philammon II are all found travelling to Hermopolis and neighbouring Antinoopolis in order to trade, showing continuity in the family's dealings. Hermopolis featured a pluralistic religious landscape in this period: the ancient temple of Thoth (Hermes) was still active, the city hosted a vibrant pagan intellectual scene ${ }^{36}$ and a Jewish quarter. A Christian tradition preserves the story of a Manichaean Elect active in this city, around the end of

\footnotetext{
34 The exclamation 'the service of God!' (тоүє)те мппоүте). See P.Kellis V, 8о.

35 For some remarks, see P.Kellis VII, 145 .

36 Although less so than in previous centuries; see Matthews, Journey of Theophanes, ${ }^{15}{ }^{-3}$. It has been suggested, based on finds of literary papyri, that Hellenic literature remained in use here longer than for instance at Oxyrhynchus; see Peter van Minnen and Klaas A. Worp, 'The Greek and Latin Literary Texts from Hermopolis', Greek, Roman and Byzantine Studies 34, no. 2 (1993): 182-83. Such statistics are difficult to evaluate, however; see in general Roger S. Bagnall, Early Christian Books in Egypt (Princeton, NJ: Princeton University Press, 2009).
} 
the fourth century. ${ }^{37}$ Antinoopolis was for a time the seat of the Pamour family's best documented Elect associate, Apa Lysimachos, and the Teacher seems to have visited this city regularly. ${ }^{38}$ They also had contacts further south, in and from Lycopolis - the city of the Neoplatonist Alexander, who wrote against Mani about three-quarters of a century earlier, and the area in which the CMC appears to have been found. ${ }^{39}$

The traders thus had long-standing ties to important centres in Upper Egypt where Manichaeism had arrived at an early date. Still, the religious affiliation of the earliest generation of traders, Pamour I and Philammon I, is unknown. Pamour I does not use religious cues at all in his only preserved letter, P.Kellis I Gr. 66. A letter that may be ascribed to Philammon I, P.Kellis I Gr. 65, contains a broadly monotheistic, possibly Christian invocation: 'And if God bids you to save us from trouble and we survive, I shall repay your favour in full. And even if God does not, I shall do you the favour' (ll.10-15). Even if the ascription of this letter to Philammon I is correct (concerning which doubts remain), it would still not prove a Manichaean affiliation: a mainstream Christian context is possible, and would be in line with the common assumption that Manichaeism first spread among Christians. ${ }^{40}$ At the same time, an encounter with the movement in the period $c .300-325$ is in itself not unlikely, in light of the family's strong affiliation by the mid-fourth century.

As we saw in Chapter 4, the Pamour family of the mid-fourth century were part of a larger network of traders and caravan-drivers, which included figures such as Horion, Psenpnouthes I, Papnouthes, Lammon, Psais Tryphanes, Loudon II and Timotheos son of Loudon I, and Ammon the storehouse-owner. The affiliation of Horion and Psenpnouthes I with Manichaeism is certain. Ammon, too, can confidently be identified as an adherent: in P.Kellis $\mathrm{v}$ Copt. 37, he expresses sorrow because someone has mistreated 'those of this word' (ll.19-20) - a clear invocation of shared religious sentiment, to which can be compared Matthaios' similar expression in P.Kellis v Copt. 25 (see below). He also adds an appeal to God for an improvement of their situation. Papnouthes and Lammon are greeted in Makarios' P.Kellis v Copt. 19, and the former adds his own greetings to Pekysis' P.Kellis VII Copt. 78, which features a

37 Historia monachorum 10.30-35, cited and translated in Gardner and Lieu, Manichaean Texts, 121.

38 See P.Kellis v Copt. 21, 25, 29, and see P.Kellis $V$, 193.

39 P.Kellis v Copt. 19, P.Kellis VII Copt. 81. It should be noted that we cannot be sure that Alexander was actually based there when he wrote his treatise. For the CMC's origin, see Koenen, 'Zur Herkunft', 240-41.

40 Even a 'pagan' context cannot be entirely excluded, see Choat and Nobbs, 'Monotheistic Formulae'. 
Manichaean prayer. As for Psais Tryphanes, his letter P.Kellis I Gr. 73 contains no overt religious cues, although he does speak of 'the season of the new wine'

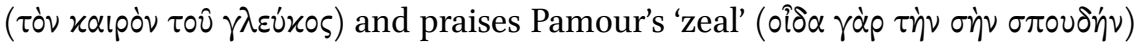
(ll.22-24) - both of which may have religious undertones, but which could simply relate to industriousness in business. ${ }^{41}$ Yet he is also respectfully styled 'father' in Pekysis' pious letter P.Kellis VII Copt. 78, and probably authored P.Kellis VII Copt. 112, which contains both the broadly Christian expression 'in the Lord' and the more peculiar 'whose name is sweet in my mouth'. It is more likely than not that Psais Tryphanes and his family shared the Pamour family's religious affiliation.

The above should suffice to indicate that Manichaean affiliation was widespread in these trading circles. How it spread remains unknown. Concrete evidence is unfortunately absent. Yet, some hypotheses may be broached. In Chapter 4, it was proposed that the traders constituted an informal association or a 'trust network', giving rise to strong interpersonal attachments. Occupational associations in the Roman period were, as a rule, also cultic associations, and there was in general a close relationship between religious observance and economic cooperation. Recent scholarship of the ancient economy has stressed how informal institutions, such as shared mental models, help to facilitate trade. ${ }^{42}$ This may have made it more difficult for new religious practices to gain entry to such networks, but could also have given added impetus for spread once initial 'converts' had been made.

The precise venue for this initial spread is hard to gauge. Did an intrigued member of the trading community take colleagues to a Manichaean gathering? Were Elect preachers involved, or did they only appear later? Did the traders meet business associates in the Valley who in turn introduced them to the movement? The Pagan philosopher Celsus, writing about two centuries earlier, accused Christians of luring gullible people 'to the wooldresser's shop, or to the cobbler's or the washerwoman's shop, that they may learn perfection.'43 Despite Celsus' disparaging and polemical intent, it should not be ruled out that for instance textile workshops may have functioned as venues for religious dissemination, and that women such as Tehat, or her counterparts in the Nile Valley, played an important role in introducing colleagues and clientele

41 It is unlikely, however, that it refers to new wine exported from Oasis to Valley, as suggested in P.Kellis I, 192.

42 Wim Broekaert, 'Going Mental: Culture, Exchange and Compromise in Rome's Trade with the East', in Sinews of Empire: Networks in the Roman Near East and Beyond, ed. Håkon F. Teigen and Eivind H. Seland (Oxbow: Oxbow, 2017), 9-13.

43 C. Cels. 3.55, trans. Chadwick, cited in Meeks, The First Urban Christians, 51. 
to the movement, although this begs the question of their affiliation in turn. One of Stark's axioms, that the religiously inactive are often susceptible to new religious movements, may be considered. ${ }^{44}$ Certainly, it must not be taken to mean that native cultic practice in general was deficient, dominated by unsatisfied 'consumers', as Stark posited, ${ }^{45}$ but zealous Manichaean adherents, such as Makarios, may well have appeared persuasive to people who were less religiously engaged. This may well have led them to follow suit - especially if he or she could depend on the arguments and authority of 'holy men', such as Apa Lysimachos.

At the same time, while trade concerns are prominent in the letters, it should not blind us to the fact that Manichaean affiliation was not restricted to traders. It is unlikely that all the households greeted by Makarios and Matthaios (for which, see below) were trading families. The community included weavers and camel drivers, roles that admittedly overlapped with trading in the case of the Pamour family; it extended to the neighbouring carpenters, and to local farmers, such as the tenant farmer Kome (see below). Elias, an agent for a landlord, may well have been an affiliate, although the evidence is circumstantial. ${ }^{46}$ The influential figures of Pebos and his brother Horion, sons of Tithoes, may be identifiable with co-adherents found in the Coptic material, although again the evidence is not conclusive, as we saw in Chapter 4. We can add that Matthaios, writing from Antinoopolis in P.Kellis v

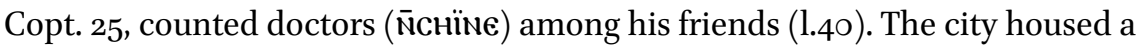
medical school, and so Matthaios - if we take his assertion at face value - had gained friends in what one may loosely term intellectual circles. ${ }^{47}$ The Elect Apa Lysimachos, too, was based here, and Matthaios otherwise reports on the doings of him and the religious community in this letter. It is therefore tempting to suggest that he could have come to know these doctors through shared Manichaean affiliation. Going by the account of Alexander of Lycopolis, the

44 Stark, The Rise of Christianity, 19.

45 For a critique, see Leif E. Vaage, Religious Rivalries in the Early Roman Empire and The Rise of Christianity (Waterloo: Wilfrid Laurier University Press, 2006). See also Jan N. Bremmer, The Rise of Christianity through the Eyes of Gibbon, Harnack, and Rodney Stark (Groningen: Barkhuis, 2010), 47-63.

46 His interlocutor Psais, who invokes shared religious affiliation in P.Kellis I Gr. 68, could well be one of the Psais' of the Pamour family. Furthermore, the name of 'lord father' Bemophanes in P.Kellis I Gr. 75 could contain an allusion to the Manichaean Bema festival, where a raised platform $(\beta \hat{\eta} \mu \alpha)$ was built to celebrate the appearance $(\varphi \alpha \dot{\eta \eta} \varsigma)$ and future return of Mani. The name is to my knowledge unknown elsewhere in Egypt; a search in Trismegistos gave no other occurrences (5/2/2017), and see P.Kellis I, 197.

47 See C. H. Roberts, The Antinoopolis Papyri. Part I. (London: Egypt Exloration Society, 1950), 70 . 
religion had piqued the interest of the literati of Upper Egypt at an early date. Doctors were not in the upper elite of Roman society, but many would have been literate, and medical professionals may well have been drawn to the movement, perhaps intrigued by its dietetic theories. ${ }^{48}$ To be sure, this remains a hypothesis that cannot be conclusively proven. It remains at any rate the case that Manichaeism at Kellis was not restricted to traders.

\subsection{A Notable's Patronage Network}

Another social site where religious affiliation can be detected is the network of the influential local notable Pausanias. Along with his associate Pisistratos, he is in fact the earliest identifiable actor of Manichaean persuasion in the Kellis material. It has already been argued that he should be identified with the ex-magistrate Pausanias son of Valerios, active in Kellis $c .320-340$. Evidence for Pausanias' religious affiliation comes in the form of P.Kellis I Gr. 63, a letter he and Pisistratos received from a certain 'father' N.N. It contains elaborate phrasings and Manichaean cues, in response to gifts they had provided for the author, his brothers, and a certain 'lord [..]ryllos', an act of charity that should be understood within the framework of Manichaean almsgiving (see Chapter 8, Section 2.3).

The rest of Pausanias' preserved documents do not display any particular religious leanings, nor can we assume that Pausanias ever used his office in order to promote the movement. However, the material does illustrate that he was well-positioned to facilitate dissemination of the religion in the Oasis. His importance in the village at large has already been pointed out in Chapter 4 . The image provided below (Chart 4) is an outtake - a so-called ego network of the village network chart from that chapter (Chart 1). It has one in depth, displaying the immediate connections of Pausanias himself. It presents Pausanias' known affiliates and illustrates his different roles: as a Roman official, through the petition from Sozomene and an order from the council-president Heron, and as a local grandee, through orders to the landowner Kome and the carpenter Ploutogenes son of Pataias.

It is unlikely to be a coincidence that we find Manichaean affiliates among Pausanias' associates, such as Psais II. Although we do not have letters by Psais II, son of Pamour I, employing Manichaean cues, his affiliation with the movement is overwhelmingly likely (and he is greeted by Matthaios in

48 For literacy among doctors, Harland, Associations, 42; for the relationship between Manichaean etiology and ancient medical discourse, see Jason D. BeDuhn, 'A Regimen for Salvation: Medical Models in Manichaean Asceticism', Semeia 58 (1992). 


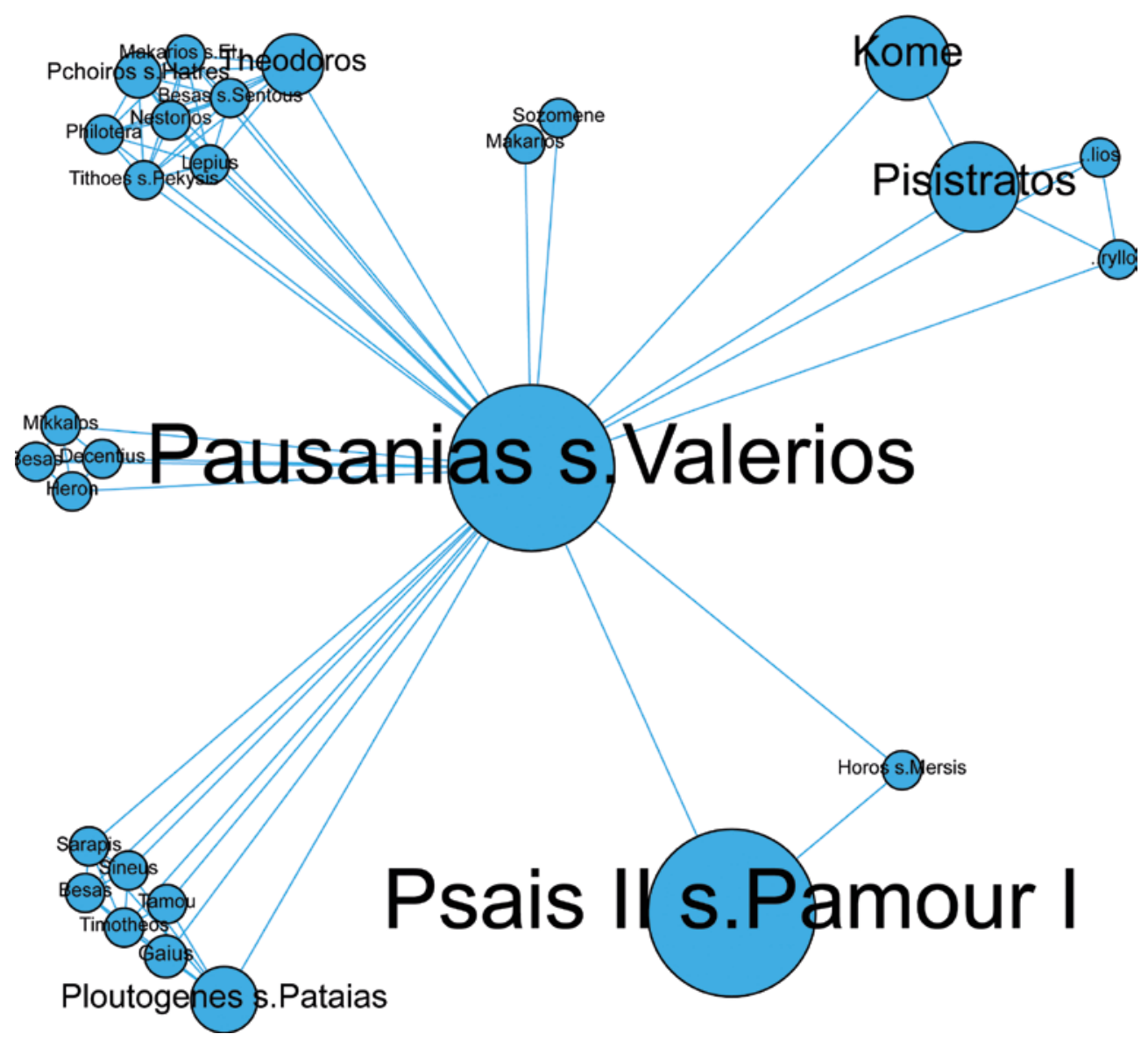

CHART 4 The ego network of Pausanias

P.Kellis v Copt. 25, see below). The text that documents their relationship is a gift donation from Pausanias to Psais, whose opening passage reads: ${ }^{49}$

Aurelius Pausanias son of Valerius, former magistrate of the city of the Mothites, to Aurelius [Psai]tos son of Pamour, from the village of Kellis belonging to the same city of the Mothites. I acknowledge that I have

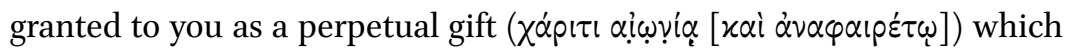
cannot be withdrawn, from now onwards for ever, from the plots of land belonging to me in the Eastern part of the village of Kellis a plot for

49 The document was found in two copies, P.Kellis I Gr. $38 \mathrm{a}$ and b, which complement each other, and provide certainty to some of the reconstructions. 
building, at the South and the North being fifteen carpenter's cubits long, at the East and at the West being twenty-five cubits.

P.Kellis I Gr. 38a, ll.1-9

The recipient, Psais II, gains full right of usage of the property previously held by Pausanias. The specific background for the transaction cannot be known. The two men did own (other) properties in close proximity to each other, and so would presumably have been familiar from before. Furthermore, in a major-

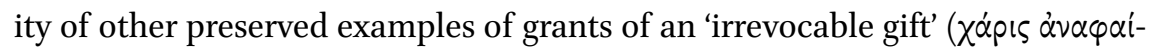

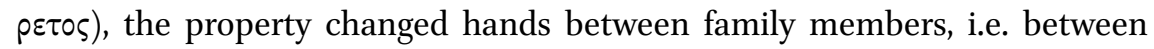
people with intimate ties..$^{50}$ No pre-existing kinship tie between Psais II and Pausanias is known to us, nor does one seem likely to have existed. Another type of strong tie must form the background for the transaction, and shared Manichaean affiliation is an obvious candidate.

In addition, we can adduce Kome, who acts as an agent on behalf of Pausanias and Pisistratos in the potsherd O.Kellis I 85. As we saw in Chapter 4, he can be identified with an important landowner in the КАв. One of his associates in that document is Timotheos the monk. This Timotheos can, in turn, be identified as an Elect, active in House 1-3 circles (see Chapter 8, Section 1). If so, an affiliation between Kome and Manichaean circles was maintained into the later fourth century, involving some sort of economic cooperation with the Elect, and even a donation of a child to the Church - if, as Bagnall thinks, Timotheos the monk should be identified as son of Kome. Bagnall proposed that the support of Kome may have been instrumental in gaining a lease of land for a topos Mani in the area Kellis. ${ }^{51}$ In turn, Kome's own affiliation with the group could well have been influenced by Pausanias.

Pausanias was clearly a central figure in Kellis in the 330s, and may well have acted as a patron for the local Manichaean community. Patronage was a core feature of the Roman social order, tying the landowning but largely city-based elite both to the urban plebs and to the rural hinterland. ${ }^{52}$ Religion was often

$50 \quad$ See the introduction to P.Col. 274 in Roger S. Bagnall and Dirk D. Obbink, eds., Colombia PapyriX (Atlanta: Scholars Press, 1996), 107.

$5^{1}$ Concerning whether the monk Timotheos, agent and perhaps son of Kome, belonged to the topos Mani of the monk Petros, Bagnall writes: 'It is not, of course, necessary to assume that the two monks were part of the same monastic establishment. But if they were, the fact that Nos' father Kome was the largest single tenant in the КАВ might help to explain how the monastery of Mani came to hold some orchard land as tenant.' P.Kellis $I V, 82$.

$5^{2}$ The fourth century saw some changes in the social organisation of patronage, as peasants of this period could appeal to different, competing elite groups. Peter Garnsey and Greg 
woven into ties of patronage. Roman officials and local notables acted as patrons for religious associations, and drew dependents and others into religious associations in which they themselves participated. ${ }^{53}$ Wallace-Hadrill, based on the work of Richard Saller, has defined patronage as a 'social relationship which is essentially (i) reciprocal, involving exchanges of services over time between two parties, (ii) personal as opposed to e.g. commercial, and (iii) asymmetrical, i.e. between parties of different status. ${ }^{54}$ Unfortunately, our evidence only allows us glimpses of these relationships. Pausanias' tie with Kome is only documented in O.Kellis I 85, and can only be shown to fulfil the last criterium, i.e. being asymmetrical. Pausanias' tie with Psais II is only documented in P.Kellis I Gr. 38, and is both personal, asymmetric, and probably long-lasting: although we cannot be entirely sure of its temporal extent, or what types of services Psais II provided in return, the appearance of other documents pertaining to Pausanias in House 3, as well as the intimacy implicit in the gift, suggest an ongoing, underlying relationship. We cannot know the specific background for these relationships, yet it is likely that Manichaean affiliation would have come to play an important role over time. It may, then, well be that Pausanias' clients had emulated him in adapting his religious allegiance, whether out of respect, persuasion, or to gain favours.

In this context, we may broach the possibility that Pausanias had furnished the local community with a church building; specifically, the West Church. There are several ostraka which link Pausanias and Pisistratos directly to this building. ${ }^{55}$ Other documents belonging to Pausanias (for which, see below) were found in structure $\mathrm{D} / 8$, located close by. Moreover, numerous other links to the circles of House 3 are found in the ostraka here. ${ }^{56}$ These finds are unlikely

Woolf, 'Patronage of the Rural Poor in the Roman World', in Patronage in Ancient Society, ed. Andrew Wallace-Hadrill (London: Routledge, 1989), 164-66.

A notable example is a Dionysian association led by the high priestess Pompeia Agrippinilla. Her husband was M. Gavius Squilla Gallicanus, consul in 150 CE and proconsul of Asia in $165 \mathrm{CE}$. The association drew many of its more than 400 members from the network of Agrippinnilla and her husband's family in the province of Asia. Harland, Associations, 30. More generally, see ibid., ${ }^{138-55}$.

54 Andrew Wallace-Hadrill, 'Introduction', in Patronage in Ancient Society, ed. A. Wallace-Hadrill (London: Routledge, 1989), 3.

55 Both occur in O.Kellis I 85, Pausanias recurs in O.Kellis I 137, Pisistratos in O.Kellis I 58.

56 O.Kellis I 137, mentioning Pausanias, features Nestorios, a name that only occurs once elsewhere at Kellis, in Pekysis' letter P.Kellis I Gr. 72. The same potsherd features Makarios, Theodoros, and Lepius, to which can be compared the trio Makarios, Theodoros, and Leporius in Tehat's letter P.Kellis v Copt. 43 (for 'Lepius' as short for Leporius, see O.Kellis I, 123). Other names that link the West Church to the House 1-3 network include, among others, Petros in e.g. O.Kellis I 114, Syros son of Psais (a lodger of the Pamour family, see P.Kellis I Gr. 45) in O.Kellis I 84 and 111, Makarios and Aionianos in O.Kellis I 288, Paulos 
to be a coincidence. The church was built 'probably not much later than the middle of the century'.57 Could Pausanias or Pisistratos have been involved in funding its construction? And if so, was it built specifically for the Manichaean community? To be sure, without direct evidence, a Manichaean context for the West Church remains hypothetical, yet the existence of a building set apart for religious activities and belonging to the community in Kellis is highly plausible (see Chapter 9, Section 3.3).

At any rate, Pausanias likely played an important role for the community on a more general level. As we saw in Chapter 2, the Dakhleh Oasis had a fairly narrow administrative and economic elite. As a magistrate of the Great Oasis, i.e. of both Dakhleh and Khargeh, Pausanias' influence was far-flung, as also confirmed by the petition P.Gascou 69, sent by Sozomene, daughter of an ex-magistrate of Hibis. The Manichaean network of House 1-3 extended to communities in Hibis (see P.Kellis VII Copt. 111, 118). Pausanias may have been central in providing a link between the disparate communities of the two oases, at least for the duration of his office(s) and before direct links were established. It is perhaps unlikely that he mediated the initial contact between the local traders and the Manichaean community in the Nile Valley: considering the long-standing ties of the traders to Upper Egypt, and the close ties between Elect and traders in the Valley, it is perhaps more likely that they first came into direct contact with Manichaean circles there. Another possible route of connection between Pausanias and Manichaeism could be the circles of local notables. Manichaeism had, already by the fourth century, gained some adherents in segments of the curial class that filled political office. This is shown by Diocletian's edict of 302 issued at Alexandria: it ordered Manichaean leaders (Elect) to be burned, and their followers (Auditors) to receive capital punishment, but explicitly excluded those of high birth and public office, who were only to lose their property and be put to hard, manual labour in the mines. ${ }^{58}$ Unfortunately, we do not know the religious affiliation of contemporary notables such as Gelasios, Harpokration, or Faustianos. Whether Pausanias was a lone swallow, or part of a larger, elite Manichaean network, remains unknown.

Much remains uncertain concerning Pausanias affiliation and his role within the community. There are, however, strong reasons to think that he cultivated ties of patronage with local adherents, and he would have provided the

(see P.Kellis v Copt. 42) in O.Kellis I 79, Dorotheos (see P.Kellis vir Copt. 107) in O.Kellis I 118, and perhaps Mour son of Psais (for Pamour III?) in O.Kellis I 94.

57 Gillian E. Bowen, 'The Coins from the 4th Century Churches and Christian Cemetery at Ismant el-Kharab', The Numismatic Chronicle 170 (2010): 482.

$5^{8} \quad$ See Gardner and Lieu, Manichaean Texts, 118. 
community with local legitimacy, resources, and support vis-à-vis the Roman administration, aiding the recruitment of adherents from circles beyond those of the traders.

\section{$2.5 \quad$ Beyond House 1-3}

This leads us to another question, namely: how common was Manichaean affiliation in Kellis, outside of what can be gleaned from the House 1-3 material itself? Finds of literary texts from other fourth-century locations have so far been sparse. Yet, as we shall see, several finds do support a picture of widespread Manichaean presence in Kellis.

First, we may note the discovery of a fragment of a Syriac text, P.Kellis VI Syr. 2, in the domestic structure $\mathrm{D} / 8$, north of the Main Temple and a good distance away from House 1-3. The text is largely illegible, but, as Franzmann, points out, all other Syriac texts from Kellis are found in House 1-3, and probably of Manichaean provenance. ${ }^{59}$ The usage of Syriac by the Manichaean community provides the most likely explanation in this instance as well. $\mathrm{D} / 8$ also yielded two Sahidic Coptic letters, a wooden board with a non-Sahidic Coptic text, magical texts, and Greek papyri relating to the Roman administration. ${ }^{60}$ Two texts in the last group, P.Gascou 69 and 71, are addressed to Pausanias son of Valerios and found in two separate rooms. They provide a direct link to Manichaean circles, and suggest that Pausanias made use of the structure at some point. In the same room as P.Kellis vi Syr. 2 were found three letters belonging to an official named Petechon, probably identifiable with an official by that name in a House 3 letter. ${ }^{61}$ This structure, then, may have been used by local officials, and the finds suggest that Manichaeism was spreading in their circles. On the other hand, Petechon's letters contain nothing else to identify him as an adherent. A Sahidic letter also found in D/8, P.Kellis viI Copt. 128, seems to belong to a mainstream Christian context, insofar as its religious content can be placed. ${ }^{62}$ This should caution against a simple association between finds, find-site, and religious identity, and further comments will have to await full publication of the site. Yet it does indicate that Manichaean literature reached beyond House $1-3$.

The other site from where Manichaean material has been recovered in Kellis is House 4. As we shall see below, here we have stronger indices that

$59 \quad$ P.Kellis VI, $136-37$.

6o See, respectively, P.Kellis viI Copt. 127-128, P.Kellis vir Copt. 131, and Worp, 'Miscellaneous New Papyri', 3

61 P.Gascou 72, 8o, 81 (D/8, Room 1); and P.Kellis I Gr. 69 (House 3). His office goes unmentioned, unfortunately.

62 P.Kellis VI, 295-96. 
we are dealing with another local circle of Manichaeans. House 4 is a domestic complex in the western part of Area A, again at some distance away from House ${ }^{-}-3$, close to Area D and the Main Temple. The structure is architecturally quite different from the House $1-3$ complex: it is larger, and the inhabitants may have been wealthier. It, too, probably housed several families. ${ }^{63}$ One part of the complex contained two Sahidic Coptic letter, P.Kellis viI Copt. 123 and 124. Both dialect and content contrast markedly with the House 1-3 letters, for instance in their use of Old Testament allusions, and they may well belong to mainstream Christian circles. ${ }^{64}$ Another part, however, produced a Manichaean hymn on a wooden board, T.Kellis II Copt. 7.65 It is of unambiguously Manichaean extraction; most notably in its praise of Mani himself, but also, for instance, in its reference to the suffering Light Elements and in its praise of the sun and moon (see Chapter 7 , Section 2.1.1).

Other documents from the house may clue us into the people who owned this prayer; most prominently the Coptic letter P.Kellis viI Copt. 122. It was found in the same room and deposit level as the hymn-board, Room $1 B$ (dep.2), and is written in the same $L^{*}$ dialect used in House $1-3$ texts - a peculiar version of this dialect most closely related to that found in the Coptic accounts and a letter attributable to Tehat (P.Kellis v Copt. 50). ${ }^{66}$ The letter is authored by the 'sons' Psais and Masi, to their 'father' Sarapas, with greetings to a 'brother' Sarapis and a little girl. The brothers had left Kellis and were now located elsewhere. While these figures are not easily identifiable with actors in the Coptic House 1-3 material, the recipients can be related to individuals featuring in the КАВ: a storehouse-owner named Sarapas, an agent named Sarapis, and his unnamed daughter. ${ }^{67}$ Other ties to the KAB, as well as the Pamour family, are in evidence. A Papnouthes is greeted as a 'brother'; this was the name of the most important agent of the КАВ manager, as well as of an important Pamour associate. The rest of the names are Pakous, Chares, and Philammon (Lammon), caravan drivers acting as intermediaries between the brothers and the father, likely related to associates of the Pamour family of these names

63 See the 'Appendix' in Bagnall and Worp, 'Two 4th Century Accounts', 508-9.

64 As argued in P.Kellis VII, 263-64.

65 Originally designated A/6/14. See P.Kellis II, 50-54.

66 P.Kellis VII, 265-66.

67 See P.Kellis IV, 72. The name Sarapas, clearly distinguished from 'Sarapis', only occurs in this letter and for the manager in the кАв. For Sarapis, see perhaps P.Kellis I Gr. 76, where Pekysis writes to 'brother' Sarapis, and note that a Sarapis worked with a Pekysis in the КАВ (1691). 
similarly engaged with camel driving and freight. ${ }^{68}$ As to religious cues in the letter, Psais and Masi greet Sarapas with the expression 'in the Lord', as well as the more distinct phrase 'whose name is sweet in my mouth' (P.Kellis VII Copt. 122, ll.1-4) and add a prayer for God to guard him: pieties often found in the House 1-3 texts, as discussed in Chapter 7 , although neither can be definitely described as specifically Manichaean.

The editors carefully point out that the Manichaean hymn-board was found near the surface level, and that although it cannot have blown in, it could have been discarded later and not belonged to the inhabitants of House $4 .{ }^{69}$ Fragments of a prayer in Sahidic was found (partly) in the same room, its contents seem to be largely 'mainstream' Christian. ${ }^{70}$ Yet, that P.Kellis VII Copt. 122, found in the same room and deposit level, is written in a dialect similar to, furnished with some of the same cues as, and probably featuring some of the same people as the House 3 letters, makes it unlikely that the presence of the hymn should be interpreted as a chance occurrence. It rather suggests the existence of a wider $L^{*}$-writing community in Kellis closely linked with Manichaean adherence.

A Greek account from the same room, P.Bingen 120, seem to pertain to this circle. It should probably be dated $366 / 7$, and so is contemporary with the KAB. Agents of the KAB manager are found among the business associates of its author. ${ }^{71}$ The combination of shared find-site and ties to the estate of the KAB speaks to the large probability that these two documents belonged to the same circle: that of Sarapas. It, too, features a Papnouthes, who may represent a direct link to P.Kellis VII Copt. 122 (and House 3), as well as the name Pisistratos, perhaps providing a link to the circle of Pausanias.

A final document needs to be seen in conjunction with the above. In 2018, a letter in Greek from a different part of the House 4 complex was published. ${ }^{72}$ It was sent from a person of religious authority named Theodoros, addressing three figures: father Psais, 'katholikos and priest' ( $\kappa \alpha \theta 0 \lambda \iota \kappa \hat{\omega} \varkappa[\alpha]$ ! $\pi p[\varepsilon] \sigma[\beta]$

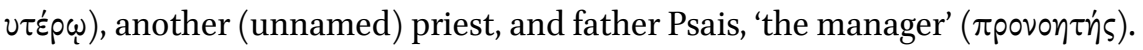

68 For the status of these figures as camel drivers in P.Kellis vir Copt. 122, cp. 1l.25-26 and 1l.32-35. For House 3; Philammon II the camel-driver in P.Kellis I Gr. 79; Chares in P.Kellis VII Copt. 66, 76; Pakous in P.Kellis viI Copt. 77.

$69 \quad$ P.Kellis VII, 263.

$70 \quad$ P.Kellis VII Copt. 126; see P.Kellis VII, 284-85.

71 Korau and Papnouthes, both names of agents of the KAB manager. The former name is rare, and should almost certainly be identified with this agent. Bagnall and Worp, 'Two 4th Century Accounts', 5 o6.

72 Inv. P93.103 (Room 13, dep. 2). Iain Gardner and Klaas A. Worp, 'A Most Remarkable Fourth Century Letter in Greek, Recovered from House 4 at Ismant el-Kharab', Zeitschrift für Papyrologie und Epigraphik 205 (2018). 
Theodoros uses elaborate and peculiar religious cues. Some features are seemingly at odds with Manichaean provenance - an apocryphal citation attributed to the prophet Jeremiah, ${ }^{73}$ and the absence of distinct Manichaean opening and closing greetings. At the same time, there are several strongly Manichaean notions present: the partial truth of all human religious writings, the sobering

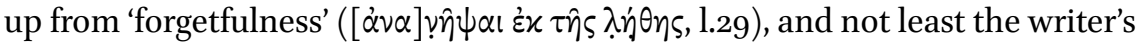

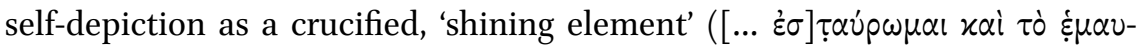
$\tau[0] \hat{\nu} \varphi \omega[\tau \varepsilon] !\left[\nu_{0}\right] \nu, l_{.30}$ ). The same room and deposit contained P.Bingen 119, an account similar to P.Bingen 120 , showing ties to the $\mathrm{KAB}$ and perhaps to House $1-3 .{ }^{74}$

Again, proper evaluation of the House 4 material will have to await full publication of the site, but a hypothesis may be broached. The documents from Room $1 \mathrm{~B}$ belonged to the family of Sarapas, a storehouse-owner in the КАВ and recipient of P.Kellis VII Copt. 122. Sarapas' circle did business with associates of the Pamour family, and perhaps had ties to Pisistratos. While other families in the same housing complex may have had more 'mainstream' Christian affiliation, the circle of Sarapas were Manichaeans: part of the same network of adherents to which the Pamour family and Pausanias belonged. Certainly, the find of Manichaean literature from House 4, and the Syriac fragment from D/8, show that the religious community extended much beyond the immediate circles of the Pamour family.

\section{Counting Manichaeans}

\section{1} The Letters of Makarios and Matthaios

Above, we have seen that Manichaean affiliation extended through several different networks and circles in Kellis. In the following, we shall attempt a rough calculation of the number of Manichaeans in the village, using two letters found in House 3 as our starting point: Makarios' P.Kellis v Copt. 19 and Matthaios' P.Kellis v Copt. 25. They contain greetings to extensive lists of

73 It should be mentioned that the Manichaean hostility to Jewish writings is often overstated; see Funk, 'Mani's Account', 122-24.

74 Such links include: the actors Pharites (agent in P.Bingen 120), Hermesias (manager in the КАв), Elias (a Pamour contact and agent of a landowner, dealing with Mesobe), and an Ammon travelling to Hibis (see P.Kellis VII Copt. 118?), and two place names, Mesobe (see above) and Thio (a village where we find a Manichaean family, see P.Kellis v Copt. 19, below). 
neighbours and associates, who were, as we shall see, considered part of the local Manichaean community. Jean-Daniel DuBois has previously suggested that Matthaios' letter would be a good place to start for such an undertaking. ${ }^{75}$ Its greetings provide the most complete snapshot we have of the Pamour family's social circles at any one time. It can be compared to the roughly contemporary letter of his 'father' Makarios, which also greets a substantial number of people. Both letters contain several names that are lost in lacunae, and a substantial number of people that are mentioned indirectly. In each case, we shall present both a 'minimum' and a 'maximum' estimate of the number of people implied in the collective greetings and lacunae.

The greetings in Makarios' P.Kellis v Copt. 19 are primarily to individuals, of whom about 23-24 names are well preserved (including the recipients themselves, Maria I and Matthaios). Some individuals are greeted together with unnamed relatives, by familial terms such as 'his father' or 'her children'. In the first estimate, I count every instance of a familial term in the plural at a minimum of two. For the 'maximum', I reckon one extra person in each plural term (i.e. altogether three). One group is specified as located outside of Kellis: a greeting to 'Partheni and Pena, and all in Thio' $(11.76-77) \cdot{ }^{76}$ The number of people implied by 'all in Thio' cannot be known; I here estimate a 'minimum' of five, including the named women (one 'small' household: Partheni, Pena, and two family members), and a 'maximum' of ten (two 'large' households, one of Partheni and one of Pena). ${ }^{77}$ This gives a number somewhere between 40 and 49 people (see below, Table 4). The majority of known addressees are women: about 20 out of 26 cases where gender can be determined. The strong prevalence of women greeted suggests that many of the men are absent. The number of people belonging to Makarios' intended audience, but not mentioned, is thus probably much higher.

Turning to the closing greetings of Matthaios' letter P.Kellis v Copt. 25 (below, Table 5), about 19 names are preserved. Naturally, there is much overlap

75 Jean-Daniel Dubois, 'Une lettre du manichéen Matthaios (P. Kell. Copt. 25)', in Coptica, Gnostica, Manichaica: Mélanges offerts à Wolf-Peter Funk, ed. Louis Painchaud and Paul-Hubert Poirer (Québec: Les Presses de l'Université Laval (éditions Peeters), 2006), 236.

76 For the location of Thio, a hamlet in the vicinity of Kellis, see P.Kellis IV, 73-76. It is notable that Kapiton son of Kapiton is described as residing in Thio at a later date (P.Kellis I Gr. 45 , dating to 386 ).

77 For the (rough) household size used in the estimate for these two, see Bagnall and Frier, cited below. 
between the two letters. Of those that do not recur, we find that [...]fnoute, $\mathrm{Mo}[. .$.$] , Drousiane, Kyria (daughter), Kame (I and II ), Lammon, Pion, Pena,$ and [..]aeis appear only in Makarios' letter; Andreas, Pekysis, Phila, and Marsa only in Matthaios' letter. However, Makarios certainly knew Andreas, Psais II, Pamour III, and Pekysis, all of whom occur in other letters by him; Matthaios would likewise have known most or all the people named by Makarios. Space, absence, or other factors may have caused them to omit certain names. Furthermore, whereas Makarios mainly greets people individually, Matthaios also greets some collectives: in addition to spouses, siblings, and children, he greets four separate 'houses'. Some of the people he omits, then, may be covered by the general term 'house' (ei). In two cases, there could be some overlap between named individuals and collective greetings. Matthaios greets both 'my father Pshai and his wife and children', and immediately afterwards 'Pakosh and Pamour and their children and their brothers, each by name' (ll.6o-61)..$^{78}$ Presumably, these are Psais II and his sons Pekysis and Pamour III, the latter two greeted both as part of Psais' household (children), and separately, with their own siblings and children. In a similar vein, it might be that Hatres and Tsemnouthes are among the 'sons and daughters' of Philammon II and Charis, greeted in the line above (ll.62-64), although there is no corroborating evidence for such a familial tie. However, it may also be that Psais II's other children, such as Tekysis III and perhaps Psais III, are intended in the first instance, and that Pamour III and Pekysis' 'siblings' include in-laws and colleagues such as Kapiton I or Theognostos.

All the other greetings are clearly to separate groups. Counting every occurrence of the plural 'children', 'brothers', etc. at two, adding another person for each 'house', and taking Hatres and Tsemnouthes to be among the 'sons and daughters' of Philammon and Charis, gives a minimum of 53 of people. Adding another person per house as well as another child per plural occurrence (i.e. assuming three children on average), adding two children to Psais II in addition to Pamour III and Pekysis (e.g. Tekysis III and Psais III), and separating Hatres and Tsemnouthes from Philammon/Charis, gives a 'maximum' of 76 people.

78 Maria (I) and Partheni (II) are mentioned in the passage immediately before this group of greetings, providing additional evidence that these two should be taken as the spouses of Pamour III and Pekysis, respectively. 
TABLE 4 Makarios' greetings (P.Kellis v Copt. 19)

\begin{tabular}{|c|c|c|c|c|c|c|}
\hline Line & Term & Name & Greeted with & Minimum & Extended & Note \\
\hline 1.46 & Mother & Tamougenia & & 1 & 1 & \\
\hline $11.46-47$ & Brother & {$[.$.$] fnoute$} & & 1 & 1 & \\
\hline $1.5^{2}$ & Sister & N.N & & 1 & 1 & \\
\hline 1.53 & Daughter & $\mathrm{E} \ldots$ & & 1 & 1 & \\
\hline 1.53 & Daughter & Tshsemnoute & & 1 & 1 & \\
\hline 1.62 & Daughter & Drousiane & & 1 & 1 & \\
\hline 1.62 & Daughter & Tshsemnoute & & 1 & 1 & \\
\hline 1.63 & Daughter & Kame & & 1 & 1 & \\
\hline 1.63 & Sister & Isi & & 1 & 1 & \\
\hline 1.63 & Sister & $\mathrm{Mo}[\ldots]$ & & 1 & 1 & \\
\hline 1.64 & Sister & Kame & & 1 & 1 & \\
\hline 1.64 & Mother & Talaphanti & children & 3 & 4 & \\
\hline 1.65 & Woman within & N.N & children & 3 & 4 & \\
\hline l.70 & Sister & Charis & & 1 & 1 & \\
\hline l.71 & Sister & N.N & children & 3 & 4 & \\
\hline 1.71 & Brother & Philammon & & 1 & 1 & \\
\hline 1.72 & & N.N & & 1 & 1 & \\
\hline 1.72 & & Pion & & 1 & 1 & \\
\hline 1.72 & Mother & Tshmshai & & 1 & 1 & \\
\hline $\mathrm{l} .73$ & Daughter & Kyria & & 1 & 1 & \\
\hline l.75 & & Lamou & mother, father & 3 & 3 & \\
\hline ll. $75^{-76}$ & & Tapsais & & 1 & 1 & \\
\hline 1.76 & Mother & Partheni & & 1 & 1 & \\
\hline ll. $76-77$ & Mother & Pena & all in Thio & 4 & 10 & \\
\hline add; 1.87 & Brother & Matthaios & & 1 & 1 & By Piene \\
\hline add; 1.88 & Mother & Maria & & 1 & 1 & By Piene \\
\hline 1.88 & Brother & Hatres & & 1 & 1 & By Piene \\
\hline 1.88 & Brother & A..e s.Hermeh & & 1 & 1 & By Piene \\
\hline 1.89 & Brother & {$[.$.$] aeis$} & & 1 & 1 & By Piene \\
\hline Total & & & & 40 & 49 & \\
\hline
\end{tabular}


TABLE 5 Matthaios' greetings (P.Kellis v Copt. 25)

\begin{tabular}{|c|c|c|c|c|c|}
\hline Line & Description & Preserved name & Greeted with & Minimum & Maximum \\
\hline 1.60 & Sister & Tsenpsais & & 1 & 1 \\
\hline 1.60 & Father & Pshai & wife, children & 2 & 4 \\
\hline 1.61 & & Pekosh, Pamour & children, brothers & 6 & 8 \\
\hline 1.62 & Father, mother & Philammon, Charis & sons, daughters & 4 & 6 \\
\hline 1.63 & & Hatres & wife, children & 4 & 5 \\
\hline 1.64 & & Tsemnouthes & children, husband & 4 & 5 \\
\hline 1.65 & & Phila & husband & 2 & 2 \\
\hline $11.65^{-66}$ & Father, mother & Psemnouthes, Kyria & N.N. & 2 & 4 \\
\hline $11.66-67$ & & Tsemnouthes & N.N., son/children & 2 & 4 \\
\hline 1.67 & Mother & Tamougenia & & 1 & 1 \\
\hline 1.68 & & A $\ldots$ & mother, N.N & 3 & 3 \\
\hline 1.69 & & Isi & N.N & 2 & 3 \\
\hline 1.69 & & Marsa & $\begin{array}{l}\text { brothers, children, } \\
\text { whole house }\end{array}$ & 5 & 8 \\
\hline $11.70-71$ & Mother & Tapsais & children & 3 & 4 \\
\hline $\mathrm{l} .71$ & Mother & Talaphanti & children, whole house & 4 & 6 \\
\hline 1.72 & Mother & Louiapshai & children, whole house & 4 & 6 \\
\hline 1.73 & Brother & Andreas & whole house, people & 4 & 6 \\
\hline Total & & & & 53 & 76 \\
\hline Average & & & & 3.1 & $4 \cdot 47$ \\
\hline
\end{tabular}

\subsection{Kellis Households and Egyptian Demographics}

In order to examine the plausibility of this range for the size of the 'houses', we can again draw on Bagnall and Frier's study of Egyptian demographics. They reckoned that 'the average attested size of Egyptian families is about 4.4 persons. ${ }^{79}$ The average size of conjugal family households they calculated at 3.43 in villages (4.86 for cities), and that of extended families at 4.47 in the villages ( 6.13 for cities). Extended families were more common in villages than in the cities, and probably made up the majority of families there. The average for the number of persons per family unit derived from the minimum count of Matthaios' letter, 3.12, is below that found by Bagnall and Frier for households of conjugal families, and much below that for extended families. The average derived from the 'maximum' count, 4.47, is identical with Bagnall and Frier's average for extended village families. One should be careful not to put 
too much weight on extrapolation from these (uncertain) averages to the concrete case of House 1-3. Still, as extended families do appear to have been more common in the countryside, the 'maximum' estimate of 76 people (with three children on average) seems more likely to be accurate.

This number must be seen in light of the suggested population of the village. It has been estimated that Kellis had a population of $c .500$ at its nadir to $c .1500$ at its zenith, and perhaps $c .1000$ in the fourth century. ${ }^{80}$ The former seems small in light of the number of people listed in the KAB alone, while the highest estimate may be somewhat large considering the abandonment of the settlement around $400 \mathrm{CE}$. Using the simple estimate of $c .1000$ individuals for the mid-fourth century given by Bagnall in P.Kellis $I V$, and taking Matthaios' greetings as a complete enumeration of Manichaeans in Kellis, the 'minimum' estimate of 53 people constitutes around $5 \%$ of Kellis inhabitants, the 'maximum' of 76 people almost $8 \%{ }^{81}$ As we saw, the latter is the more likely. Furthermore, it is unlikely that Matthaios' greetings exhausted the Manichaeans in the village: the general greeting at the end suggests that there were others he had not named. As we have seen, Manichaean affiliation was also found outside the immediate circles of the Pamour family.

\subsection{Shared Religious Affiliation}

Before drawing this conclusion, however, an urgent question needs to be addressed: can we, in fact, take the people greeted in these letters as co-adherents? Although we cannot reach absolute certainty, some observations based on the letter contents strongly suggest that we can. Most tellingly are the instances where the authors address and explicitly include them within a shared religious community. Thus, in the middle of a string of greetings to about eight women, including Talaphanti and 'the woman within' (ТР $\bar{M} \overline{2} 20 \gamma \mathrm{N})$, both with children, Makarios adds:

Tell them that I myself am very grateful to them, and God is my witness that $[\ldots]$ all in my prayers and my supplications. I [remember] you $(p l$. very very much (TONOY TONOY), praying for your health [...] night and day; just as I see you are zealous, whether I am far [from you] or near to you

P.Kellis v Copt. 19, 11.65-70

8o For the population estimates, see the section on population in Chapter 1.

81 Assuming most of them were Kellis inhabitants. The greeting from Makarios to those in Thio indicates that some lived in a nearby smaller village, but this is the only location outside Kellis mentioned explicitly. 
This heartfelt and pious expression of gratefulness, addressed to some or all of these women, include what seems to be a variant of the 'far but near' formula. Perhaps his thanks are for assistance of a specifically religious nature; at any rate, it indicates that he took their shared religious affiliation for granted. More directly, Matthaios ends letter P.Kellis v Copt. 25 by bidding Maria to greet - in extension of the other greetings listed previously - to everyone 'who

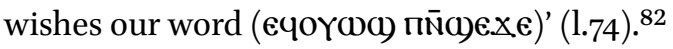

To this, we may note that both Makarios and Matthaios use elaborate cues and discuss religious affairs at some length in these letters. Makarios describes, for instance, a quarrel he has had with a deacon during his 'practice' ([Mє] $] \lambda € T \lambda, ~ l .49$ ), while Matthaios discusses the travels of the Teacher. Relating such affairs would primarily make sense if the authors thought the recipients, Maria I, Psenpnouthes I, and Kyria I, but also the people to whom they were to extend their greetings and presumably relate the letter contents, were interested in them. Not least, the lavish use of kinship terms in an extended sense - the numerous greetings to 'mothers', 'daughters', and so on - could well be anchored in shared religious affiliation, a notion of the community as a spiritual family: the 'living race/family (трєїтє €TANē)' that Makarios invokes in P.Kellis v Copt. 22 (l.5) ${ }^{83}$ There are, then, good reasons to think that Makarios and Matthaios took most or all the people they greet to be fellow-adherents. To be sure, we cannot know how many confined their affiliation to expressions of sympathy, contra how many were enthusiastically engaged in communal life and actively appropriated Manichaean notions and symbols. This is, however, irrelevant to whether they were in some sense fellow-adherents.

Finally, to prefigure later discussions somewhat, we can already note here that these estimates should make us sceptical of the notion that Manichaeans at Kellis were confined to domestic settings or intimate cells for their religious activities. The movement's repertoire of practices involved communal ritual, for which - as will be seen in the next chapters - there is indeed evidence at Kellis. As discussed above, it should not be excluded that one of the churches excavated in the village may have belonged to the Manichaean community. The size is also relevant when re-examining the common idea that Manichaeism did not appeal to people in the countryside. It is unlikely that all these families were traders, and if the group arrived in Kellis only around 300 (or later), its growth would seem to have been quite rapid. This suggests an ability to attract

\footnotetext{
82 A similar formulation is found in Ammon's letter P.Kellis v Copt. 37. See below.

83 Cf. Brand, 'Manichaeans of Kellis', 169-75. For the conspicuousness of such language in Christian contra 'pagan' circles, see e.g. Jan N. Bremmer, 'The Social and Religious Capital of the Early Christians', in Hephaistos 24 (2007): 274-75.
} 
adherents in a wider segment of the population than previously assumed, including in the countryside. ${ }^{84}$

\section{$4 \quad$ 'Open' or 'Bounded' Network?}

Having gotten a rough sense of the scale of Manichaean presence in the village, it may well be asked what the relationship between this comparatively large group and their social surroundings was. In this context, we need to address the degree to which this religious affiliation created tension with surrounding society. Within the sociology of religion, tension between a group and its social surroundings has often been expressed in terms of 'sectarianism', where the degree of tension is used to delineate between 'churches' and 'sects' (on a sliding scale). ${ }^{85}$ Tension has also been a central concept for differentiating religious groups in antiquity, used to distinguish 'open' Graeco-Roman cultic associations from 'exclusivist' synagogues and churches. ${ }^{86}$

There is little reason to doubt that Manichaeism, as traditionally perceived by previous generations of scholars, was a 'sect' on the level of religious organisation - in the non-normative, sociological sense of a group with a high degree of tension to surrounding society. The persecutions of Bahram II in the Sasanian Empire and of Diocletian in the Roman Empire demonstrate this. It is echoed by their enmity towards (hostile) political authorities, as well as towards some dominant social practices, such as blood sacrifices and meat consumption, in the authoritative Manichaean tradition. But again, as with identity more generally, it may be questioned whether such sectarianism was

84 In fact, Robinson (Who Were the First, 78) did note Manichaean missions to the villages, based on the evidence of the Acta Archelai. This text has long been considered largely fictional, and while new research indicates that the author likely had some knowledge of the biography of Mani (see Gardner, 'Mani's Last Days', 161, 96-205), the reliability of this information remains hard to judge.

85 As for instance in the work of Stark and Bainbridge, who conceptualise 'churches' as religious institutions largely integrated into the social fabric, and 'sects' as break-away groups from churches, with a high degree of tension to dominant social norms and institutions. Rodney Stark and William S. Bainbridge, The Future of Religion: Secularization, Revival, and Cult Formation (Berkeley: University of California Press, 1985), $22 \mathrm{ff}$.

86 See e.g. Meeks, The First Urban Christians, 78-80; Keith Hopkins, 'Christian Number and its Implications', Journal of Early Christian Studies 6, no. 2 (1998): 217-18; J. B. Rives, 'Christian Expansion and Christian Ideology', in The Spread of Christianity in the First Four Centuries, ed. W. V. Harris (Leiden: Brill, 2005), 17-23; Mary Beard, John A. North, and S. R. F. Price, Religions of Rome (Cambridge: Cambridge University Press, 1998), 307-11 and $211-44$. 
reproduced by the laity on the level of everyday interaction. The dichotomy between 'open' and 'bounded' groups has been challenged by recent scholarship. On the one hand, scholars have pointed to exclusivist tendencies among Greco-Roman cultic associations. ${ }^{87}$ On the other, they have emphasised that boundedness and tension as a rule were products of the discourse of religious authorities, rather than experienced by adherents. ${ }^{88}$ Most people, it is argued, only rarely activated religious identity in mundane contexts. We cannot, then, take a high tension as a given. At the same time, as we saw in the foregoing chapter, we should not underestimate the degree to which the laity themselves could actively appropriate authoritative discourses and institutions. To resolve the issue, we need to assess the Kellis evidence itself.

Yet, there has been some difference in scholarly views on the level of tension on display also here. Gardner first noted that the laity displayed 'exclusionist' tendencies in P.Kellis II, stating: 'there are some of those communal characteristics to be found here as are known from the typology of sectarian movements, particularly in their earlier, world-denying stages'. ${ }^{89}$ In P.Kellis $V$, the editors adduced the use of prayers for protection from an evil world, and allusions to or even explicit mentions of persecution, as evidence for this sectarian characteristic. ${ }^{90}$ This has now been criticised by Mattias Brand, who strongly rejects the label 'sectarian'. In particular, he criticises the idea that the community experienced strong tensions with surrounding society, arguing:

[w] hile it is possible that some Manichaeans experienced maltreatment on the basis of their religious affiliation, there is no evidence for full religious persecution. Instead, just like modern minorities in Egypt, they may have suffered from petty acts of discrimination or a subordinated position in relation to other people. ${ }^{91}$

Below, we examine evidence for both participation in wider society ('positive' interaction) and 'world rejection' and tensions ('negative' interaction), and discuss some of the points made by Brand, in order to review this issue..$^{92}$

\footnotetext{
87 Harland, Associations, 19iff.

88 See the literature cited in Chapter 5 .

$89 \quad$ P.Kellis II, viii.

$90 \quad$ P.Kellis $V, 81$.

91 Brand, 'Manichaeans at Kellis', 162.

92 For the categories of 'negative' and 'positive' interaction, see Harland, Associations, 137-6o.
} 


\subsection{Positive Interaction}

There is no doubt that many adherents participated in the political and economic life of the village, and we have already surveyed much of the evidence for such engagement. As we saw in Chapter 4, Horos III son of Pamour III undertook a liturgy. The family's associate Pausanias was himself both a Manichaean and an active participant in nome administration. No open hostility towards the Roman political order can be detected in the private letters, although it should be emphasised that liturgical service was compulsory, and is certainly not a sign of support for this system, either.

More interesting are signs of cross-denominational interaction, which may be evinced by the occurrence of certain 'catholic priests' in the House 3 material. A dichotomy between a (Manichaean) 'Holy' Church, to which the most of the House 3 authors belonged, and a dominant 'Catholic' Church, with which they interacted, could be implied by these texts. Still, it may be premature to take it as a given that the term 'catholic' ( $\kappa \alpha \theta 0 \lambda(x \eta$ ) is used to designate a specific (mainstream) church organisation, as against other, competing churches. In the papyri, the term could simply refer to the main church in a village. ${ }^{93}$ The Manichaeans, too, considered their message universal, and may at any rate have preferred to use the dominant terminology in official documents. This must be kept in mind when we examine the evidence below.

One 'catholic presbyter' is found in the oft-discussed P.Kellis I Gr. 24 (352), pertaining to Ploutogenes son of Ouonsis. The term is associated with the

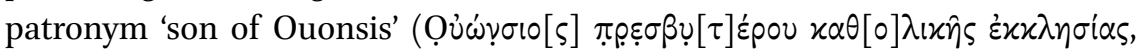
1.3). Unfortunately, the preceding words are lost. The term could either be taken to relate to Ouonsis or to a lost preceding name. ${ }^{94}$ It seems somewhat unlikely that it relates to Ploutogenes son of Ouonsis himself: the petition sent by Ploutogenes the subsequent year, P.Kellis I Gr. 23 (353), makes no mention of any religious office for him; there, he is simply one of the local komarchs. If he had been a presbyter this would presumably have emphasised. Still, it could well relate to his father, or to an unknown brother. The context for the document is one of wider village concerns, and so it does not necessarily show

93 For the argument that this term was also used among for instance the Meletians, and could simply indicate the largest church in a town, see Wipszycka, 'Katholiké.' A distinction between 'Manichaean' and 'Catholic' Christians does appear to have been recognised by Manichaeans in the Latin west, at any rate: Augustine criticises the Manichaeans for attacking 'Christians who bear the name "Catholic"' (De mor. 2.20.75, trans. Roland J. Teske, The Manichaean Debate (New York: New City Press, 2006), 103).

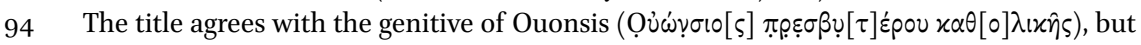
this is not decisive. Apart from as patronym, Ouonsis is only known from P.Gascou 18-19, two contracts dating to 319 and 320 , respectively. 
close interaction with the House $1-3$ people. ${ }^{95}$ But as we saw in Chapter 4 , Ploutogenes son of Ouonsis does appear to have had some kind of link to the Pamour family. If the title belonged to Ploutogenes or one of his family members, it suggests that this 'catholic' family had no trouble associating with Manichaeans or vice versa - but how and in what capacity remains obscure. Another document involving a catholic priest could pertain to the same man. It is a highly fragmented contract involving a certain Ploutogenes, dating to 337 (P.Kellis I Gr. 58). The 'catholic priest' is named [Harp]okrates, and witnesses on behalf of Ploutogenes. An identification with the son of Ouonsis is possible, but given that the name Ploutogenes is common, and that no patronymic is preserved, it remains tentative. The name is not known from elsewhere in the House 1-3 material, or even in the village at large, and so Harpokrates' role vis-à-vis the family is unknown.

The last instance is found in P.Kellis I Gr. $3^{2}$ (364), and pertains to a Jakob,

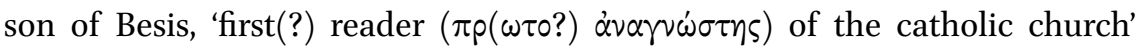
(1.21). ${ }^{96}$ It is more directly tied to the Pamour family, as this Jacob writes on behalf of an Aurelia Marsa from Kellis, who rents a room in Aphrodito from Psais (II) son of Pamour (I). In addition to the term 'catholic', the name 'Jacob' is suggestive of mainstream Christian affiliation. The name does not recur in the House 1-3 letters, and there is as such no reason to assume that he was closely affiliated with the Pamour family. ${ }^{97}$ Marsa, on the other hand, could be identifiable with Marsha, a woman greeted among the other members of the community in the above-examined letters of Makarios and Matthaios. Admittedly, in those two letters she is located in Kellis, and so the identification is not certain. If she is to be identified with this Marsha, it may well be that we can here see how certain members of the community had a pragmatic view of boundaries between different groups. Conversely, it may be that she did not consider herself part of the Manichaean community, despite the attempt of Matthaios to include her in the fold. Finally, her employment of Jacob could simply have been an act of necessity, based on a need for a literate

95 There is the question of the clergy who occur first in the list, in the same group as Psenpnouthes I, Psais Tryphanes, Loudon II, and Timotheos: Paminis the presbyter, and Pkour[..]s and Cholos the deacons. No patronymics are given, and it cannot be known whether Paminis should be identified with the 'catholic' presbyter earlier in the document, as 'son of Ouonsis', or whether he represents a different church grouping in the village. That these were Manichaean clergy certainly cannot be shown on present evidence either.

96 See P.Kellis $V$, 343 .

97 Although it should be mentioned that a Jacob 'the potter' features in an account, P.Kellis I Gr. 61. 
witness. There are in other words multiple ways in which this interaction can be interpreted.

That participation in larger economic and political structures, and interaction with people identifying with other communities, would be the norm for Auditors is not particularly striking. At any rate, it tells us little about their attitudes to them. More interesting are the activities of the monk Petros on behalf of the topos Mani, likely showing a Manichaean monastic institution dealing directly with the estate of Faustianos (see Chapter 9, Section 3.3). The religious affiliation of this landlord is unknown, although some evidence - if highly uncertain - may suggest that the local estate manager considered himself a 'mainstream' Christian. ${ }^{98}$ At any rate, if the identification of the topos with a Manichaean monastery is correct, it shows it operating as an economic entity, much like other cultic associations of antiquity, and that a depiction of the Elect simply as world-denying renouncers is too simple.

\subsection{Negative Interaction}

Alongside these signs of engagement with wider society, there are signs of anti-worldly sentiments and evidence for a high degree of tensions with surrounding society ('negative' interaction). Let us first look at the lay religious cues. Several authors utilised prayers addressed to the God of Truth for health, which in some cases were combined with another prayer for protection against 'evil' (пеөаY) or 'temptation' (прдсмүс), in line with similar use by Mani. ${ }^{99}$ Thus, Pamour III prays for his recipients being protected against 'the snares of the devil and the adversities of Satan' in P.Kellis viI Copt. 65 (ll.12-15), and again against 'temptations of Satan and the adversities of the evil place' in P.Kellis vir Copt. 71 (ll.8-9). ${ }^{100}$ Similarly, Matthaios prays for Maria to be 'free from any evil and temptation of Satan' in P.Kellis V Copt. 25 (ll.19-22), and the lost author of P.Kellis V Copt. 34 prays for his recipient to be 'free from every evil of Satan' (ll.11-12). Makarios and Matthaios include appeals for 'freedom' (парPHсla) in several letters (P.Kellis v Copt. 20, 22, 25). At the very least, these passages suggest that the Manichaean view of the world as in some sense an 'evil' place was widely shared by adherents in Kellis. This view

98 Perhaps evinced by the Greek letters $\Gamma \mathrm{MX}$ etched into the кав codex. For their possible significance, see P.Kellis $I V, 83-84$.

99 Gardner, 'Mani's Letter to Marcellus', 36 and 41; id., 'Some Comments on Mani's Epistles', $175^{-77}$.

100 For other instances of Manichaean usage of the imagery of 'snares of the devil', see Gunnar Mikkelsen, 'Augustine and his Sources: "The Devil's Snares and Birdlime" in the Mouths of Manichaeans in East and West', in In Search of Truth, ed. Jacob A. van den Berg, et al. (Leiden: Brill, 2011), 419-25. 
was not, of course, restricted to the Manichaeans, and its social significance is indeterminable - Manichaeans could certainly express positive views of the world, as well. Perhaps it might imply that the community was somewhat austere, but this cannot be measured.

In addition to prayers against cosmic evil, several references to evils taking place in this world can be detected, however, indicating social tensions. We may start with the letters of Matthaios and Makarios, whose calls for freedom may be connected to events in the Valley. These latter appeals are, perhaps, comparable to Mani's own calls for parrhesia found in the Berlin Kephalaia, as noted by the editors, who comment: 'We wonder if it is more than the tyranny of distance that keeps the family away from the oasis. ${ }^{101}$ Matthaios' prayer in P.Kellis v Copt. 25 continues with implying a degree of anxiety, alluding to hope for a meeting in the afterlife. It reads:

And furthermore I pray that this great day of joy should happen to us, the day for which we pray indeed every hour, and God grant us that we may see the image of each other in freedom and with a smiling face. Or indeed: whether they are dreams (?) or whether it is the sphere [...];102 or else again: perhaps they change and cast us once again towards you, and we will be satisfied with the face of all our beloveds. Would therefore that this may happen to us! (ll.22-30)

Considering the mundane tone concerning travel in other letters, attributing his concerns here to separation caused by physical distance between Oasis and Nile Valley alone seems insufficient. On the other hand, there is no mention of hardships or persecutions in this letter. Perhaps his heartfelt prayer could rather be seen in light of his expression of sorrow for the death of his 'great mother' found in the same letter.

The calls for freedom in Makarios' letters P.Kellis v Copt. 20 and 22 provide stronger indications of social tensions, as they relate certain events that suggest that the family was experiencing troubles. They presume current knowledge on the part of the recipients that we no longer possess, and so we should proceed with care. In P.Kellis V Copt. 20, Makarios reports that Matthaios had experienced some problems, reporting to Maria that: 'Let it be you know

101 P.Kellis $V, 82$.

102 The editors reject a restoration of this lacuna as 'stars' (NCiOY). Ibid., 192. Still, an alternate plural form of 'star' is cleoץ, which could perhaps be read by replacing epsilon for sigma. At any rate, we are dealing with some kind of astrological allusion, based on the presence of the 'sphere', and one should in this context note the Manichaean notion of astrological influence on the fate of individuals, where both demonic and divine elements played a part. 
that brother Sarmate has petitioned Pkonaes (?). He ordered Kleoboulos to return, and cause to be given back the things of Mathaios that had been taken' (ll.4O-42). This seems to relate to the confiscation of Matthaios' 'things' by a Roman official. ${ }^{103}$ In another letter, P.Kellis v Copt. 22, Makarios provides a more detailed (if still obscure) description of hardships, writing: 'How many $[\ldots]$ these or our sanctuary? Are not you yourself a catechumen? For we are not retaliating against anyone in this place for what they are doing to us' (1l.6o-62). He further mentions someone pursuing a man (or a book), and 'the fire that burns in my heart on account of the book which they took' (1l.6566). In the following, fragmented part of this passage can be read references to 'weakness', 'toil', and 'by body, by spirit' (ll.67-69), for which the context remains obscure. In the next passage, whose connection to the former is somewhat unclear, he complains to either Maria I or Kyria I that: 'You had no pity for your brother's son, because he is under persecution ( $\triangle$ IФгмос); though you know that I have spent two years without him. He has no one who can guide him but God, the one who repays' (ll.73-75).

A religious context for these incidents is, however, rejected by Brand. Regarding the confiscation in P.Kellis v Copt. 20, he argues that: " $[\mathrm{i}] \mathrm{f}$ Matthaios or his father Makarios indeed petitioned a Roman official after a theft or assault, it is most unlikely that they would have been afraid of maltreatment by the Roman authorities for their religious affiliation. ${ }^{104}$ However, while such a petition indeed shows that they had some hope of being given redress by the governor - and as we have seen, they may well have had influential contacts, - it does not imply that the religious community was on good terms with the Roman administration in general. ${ }^{105}$ Religious conflict could have flared with local officials such as Kleoboulos, who may well have been logistes of the Great Oasis. ${ }^{106}$ Regarding the event(s) in P.Kellis v Copt. 22, Brand comments that the incident concerning the book 'could have been about a failed business transaction (including books?), for which Makarios blames Maria (or Kyria)', and, regarding the matter of persecution, that 'the Coptic term

103 The editors note that the verb 'petition' (сммє) suggests that *Pkonaes should be understood as 'the komes' (ibid., 171), i.e. the praeses or civil governor of Upper Egypt (not a military official, as per Brand, 'Manichaeans of Kellis', 156).

104 Brand, 'Manichaeans of Kellis', 156-57.

105 As suggested at ibid., 156.

106 A fragmented letter or order to a logistes of the Great Oasis named Kleoboulos was found in House 3, P.Kellis I Gr. 25, unfortunately lacking a date. An Oasis official by this name occurs in M.Chr. 78 (c.376-78), travelling to Dakhleh and reporting to the praeses, and a late fourth-century landowner by this name is known from several ostraka from Khargeh Oasis. See P.Kellis I, 77 . 
persecution ( $\triangle 10$ Гм $\mathrm{MOC})$ was also used in military or legal settings. Without further context, it remains unclear whether religious persecution was meant'.107 But here he neglects to discuss the passage concerning retaliation for hostile acts at the 'sanctuary', as well as the other religious markers both in the opening and in the same passage. As argued in Chapter 5 , it is especially significant that Makarios invokes Maria I's (or Kyria I's) role as catechumen while beseeching help in these matters. These indices make a religious context highly likely.

That the community experienced such hardship is supported by an explicit reference to religious tensions in a letter pertaining to the younger generation, that of Psais/Andreas. In P.Kellis v Copt. 37, Psais III's associate Ammon writes:

Now, great was the grief that overcame me, and the heartbreak that seized me, when I heard about what happened; namely that they shook those of this word (aүkıм andmicexe). For it is possible for God to thwart their designs. In fact, I wanted to come to you, but I was told that it was not allowed. (ll.13-25)

The 'shaking' of 'those of this word' clearly describes a violent act against fellow-adherents. ${ }^{108}$ Unfortunately, no further details are given. Questions concerning where it took place, who the perpetrators were, what prevented Ammon from going to Psais III, or why that is relevant are all unanswerable. Ammon takes this information as already known to Psais III. It is perhaps possible that it was Psais II himself who had informed him in a previous letter.

A specifically religious disruption is again likely to form the background of a letter by an Elect who styles himself 'your father who is in Egypt'. In his letter, P.Kellis v Copt. 31 , he justifies his request for goods addressed to a plurality of female catechumens in Kellis by writing, in a passage that unfortunately is very lacunose, that he and his companions are 'afflicted' $(\mathrm{T} \overline{\mathrm{N}}[\lambda] \mathrm{\lambda} \times \overline{2}, 1.34)^{109}$ and that 'the place is very difficult' (пма max2 [TоNoץ], 1l.47-48). The letter ends with a mysterious instruction:

$[\ldots]$ this letter to you $(p l$.$) . When you have finished reading it, send it to my$ son with certainty. Do not let it stay with you, it may fall into somebody's hands. Indeed, what is even this constraint (†КedNar'KH)! (1l.52-55)

107 Brand, 'Manichaeans of Kellis', 16o; but cf. also the remarks on 179.

108 See the comments of the editors regarding the word KIM ('shake'). P.Kellis V, 233.

109 Crum (151a) also lists 'be crushed,' 'effaced' (as a noun 'anguish', 'oppression'). 
The mix of 'being afflicted', a sense for urgency, and a need for secrecy strongly suggests that the author and his associates are under outside pressure. ${ }^{110}$ Perhaps some exaggeration of the troubles should be allowed for, considering the letter's purpose of acquiring alms (see Chapter 8, Section 2.3), and the nature of the affliction remains obscure. But whatever the exact troubles, there is little doubt that they pertain to a specifically religious context.

There are other letters from the generation of Pamour III that contain very similar allusions to what might, potentially, be religious troubles. Pamour III alludes to difficulties in one letter, writing: 'You wrote to me: "When the place is quiet, then write to me"' (P.Kellis viI Copt. 72, ll.26-27). The significance of 'quiet' (MAT $\bar{N}$ ) is most unclear, however, and he might simply be referring to conditions pertaining to trade, as suggested by the editors. ${ }^{111}$ In a passage from a letter addressing Partheni II, Theognostos writes:

God is witness that your $(p l$.$) memory is in our heart at all times, as we$ wish to come and see you. But what can we do? For the place is disturbed now and we are afraid. Let nothing evil happen whilst the place remains disturbed.

P.Kellis VII Copt. $83,11.5^{-8}$

The disruption of the 'place' (חMd TH2), the restriction on movement (comparable to that of Ammon), the fear that Theognostos and his associates have experienced, and the potential for further 'evil' (пєедү), suggests a serious tumult. But again, the events may not relate to religious difficulties, and could pertain to broader conditions in the Oasis or the Valley.

Of the above-considered passages, we may reasonably see religious tension as forming the backdrop in the letters of Makarios (at least P.Kellis v Copt. 22), Ammon, and the Elect Father. Certainly, it is unlikely that we are dealing with full-scale persecutions. As far as can be determined, Makarios' letter belong to the mid - late 350 s and the letter of Ammon to around 370. The former, at least, is situated before the time of the edict of Valens and Valentinian against Manichaean assemblies in 373, and both were written before the harsher measures undertaken by Theodosius I. ${ }^{112}$ Singular incidents of hostility from, for

\footnotetext{
110 See P.Kellis $V$, 213. Cf. the interpretation of Brand, 'Manichaeans of Kellis', 16o.

111 P.Kellis VII, 81, 75-76.

112 For these edicts, see Per Beskow, 'The Theodosian Laws against Manichaeism', in Manichaean Studies, vol. 1. Proceedings of the First International Conference on Manichaeism, August 5-7, 1987, ed. Peter Bryder (Lund: Plus Ultra, 1988); for a broader discussion of late-Roman law and Manichaeism, see Caroline Humfress, Roman Law and the Prosecution of Heresy (Oxford: Oxford University Press, 2007), 243-55.
} 
instance, a specific Roman official (as perhaps in P.Kellis v Copt. 20) do not on their own prove a high degree of tension with society in general. At the same time, there is ample reason to see the accumulation of evidence as indicating a high level of tension. At least in Ammon's letter we are dealing with actual violence towards a plurality of adherents. The fact that they relate to different incidents, spread out over a long period and probably a wide geographical area show that difficulties were recurrent. ${ }^{113}$ Not least, that the community experienced trouble even before official sanctions began indicates that tensions were not only the product of authorities on the imperial level. These factors point to widespread and persistent tensions that, at certain points, could erupt in violence.

Brand is right in that we are not dealing with persecutions, in the sense of a deliberate program for the suppression of the group. But his argument that the problems were restricted to 'petty acts of discrimination' (cited above) is unpersuasive, insofar as it downplays the social consequences of such tensions. Even if violent eruptions were not regular, and mainly caused by small groups of 'extremists', they would have served to spread fear among other members of the group - especially if such acts had some level of acceptance in broader society or among state officials. Violence does not have to happen on a daily basis (or even be realised) in order to be effective: threats and abuse are enough to create an atmosphere of persecution, and strengthen in/out group dynamics.

\section{5}

\section{Networks, Dissemination, and Tensions}

In this chapter, then, we have found that the Manichaean community extended through several, interconnected circles in the village: within households, between neighbouring families, and among traders, and received additional support and legitimacy through an Oasis notable. The movement may have arrived in the village through the networks of the traders, although a (separate?) dissemination through the curial class cannot be excluded. However, ties of neighbourhood, kinship, and patronage would have allowed it to spread through the village at large and to include local farmers and other artisans. In this way, it came to embrace a large percentage of the village population. Moreover, the Manichaeans at Kellis did not shy away from participation

113 They may have been spread geographically as well: Ammon and his correspondent are in the Oasis, the Elect of P.Kellis v Copt. 31 are in the Nile Valley, while Makarios seems to be somewhere in between at the time of the difficulties (see P.Kellis v Copt. 22, 1.69). 
in broader social structures, and likely had relations with people affiliated with other religious communities. This should lead us to conclude that Manichaeism was not inherently a 'secretive' religion, reserved for elite members or small cells.

Yet, evidence for religious tension and violence, found in randomly preserved material spread and spread out in time, does strongly suggest that this network experienced persistent pressure. As long as the community was not too severely hit, and able to recover from such incidents, the pressure may have strengthened their sense of shared identity, and contributed to solidify a sense of distinct 'groupness' within the network - perhaps evinced by the extensive use of kinship terms by Makarios and Matthaios. At the same time, hardened group identities on both sides would have made it more difficult to reach groups beyond those already part of the network. Finally, in the long term, and as official pressure also mounted, it would have become difficult to maintain religious institutions. As a consequence, the network may well have begun to disintegrate. 